\title{
SUGARS, ORGANIC ACIDS, MINERALS AND LIPIDS IN JABUTICABA ${ }^{1}$
}

\author{
ANNETE DE JESUS BOARI LIMA², ANGELITA DUARTE CORRÊA ${ }^{3}$, \\ ANA MARIA DANTAS-BARROS ${ }^{4}$, DAVID LEE NELSON ${ }^{4}$, ANA CAROLINA LOURENÇO AMORIM
}

ABSTRACT - The aim of this work was to determine the sugar, organic acid and mineral compositions of the whole fruit and fractions (skin, pulp and seed) of the Paulista (Plinia cauliflora) and Sabará (Plinia jaboticaba) jabuticaba tree genotypes, as well as the oil compositions of their skin and seeds. High levels of sugar, especially fructose, followed by glucose and sucrose, were encountered in the fruit. In the Paulista genotype, higher levels of total and reducing sugars were found in the pulp and skin, which was not observed when comparing the whole fruit of both genotypes. Five organic acids were found in the whole fruit and in the fractions of the two jabuticaba genotypes in quantitative order: citric acid $>$ succinic acid $>$ malic acid $>$ oxalic acid $>$ acetic acid. Potassium was the most abundant mineral found. This fruit was also shown to be rich in magnesium, phosphorus, calcium and copper. The seed oil had nearly the same constitution as the oil extracted from the skin in both genotypes and the major compounds were an unidentified phytosterol, palmitic, linoleic and oleic acids, and squalene.

Index terms: Plinia cauliflora, Plinia jaboticaba, chemical constituents.

\section{AÇÚCARES, ÁCIDOS ORGÂNICOS, MINERAIS E LIPÍDEOS EM JABUTICABA}

RESUMO - O objetivo deste trabalho foi determinar a composição dos açúcares, ácidos orgânicos e minerais do fruto inteiro e frações (casca, polpa e semente) dos genótipos de jabuticabeira Paulista (Plinia cauliflora) e Sabará (P. jaboticaba), assim como a composição do óleo das cascas e sementes. As frutas apresentaram elevados teores de açúcares totais, destacando-se a frutose, seguida de glicose e sacarose. No genótipo Paulista, foram encontrados teores mais elevados de açúcares totais e redutores na polpa e na casca, o que não foi observado ao comparar os frutos inteiros dos dois genótipos. Foram encontrados cinco ácidos orgânicos na seguinte ordem quantitativa: ácido cítrico $>$ ácido succínico $>$ ácido málico $>$ ácido oxálico $>$ ácido acético. Potássio foi o mineral mais abundante encontrado. A fruta mostrou também ser rica em magnésio, fósforo, cálcio e cobre. O óleo das sementes mostrou ter praticamente a mesma constituição do óleo extraído das cascas, e os compostos majoritários foram um fitosterol não identificado, os ácidos palmítico, linoleico e oleico e o esqualeno.

Termos para indexação: Plinia cauliflora, Plinia jaboticaba, constituintes químicos.

1(Trabalho 136-10). Recebido em: 01-6-2010. Aceito para publicação em: 05-11-2010.

${ }^{2}$ Dra, Profa., Departamento de Química, Universidade Federal de Lavras, CP 3037, CEP: 37200-000 Lavras - MG - Brasil. E mail: E-mails: anneteboari@gmail.com, angelita.dqi@ufla.br

${ }^{3}$ Dra.,Profa, Depart. de prod. Farmacêuticos, E-mail: dantasb@farmacia.ufmg.br;

${ }^{4}$ Dr., Prof., Depart. de Alimentos, E-mail: dlnelson@ufmg.br; Faculdade de Farmácia, Universidade Federal de Minas Gerais, Av. Presidente Antônio Carlos, 6627.Câmpus Pampulha CEP: 31270-901 Belo Horizonte - MG - Brasil.

${ }^{5}$ Dra., Instituto de Química, Centro de Tecnologia, Bloco A,Universidade Federal do Rio de Janeiro, CEP: 21945-970 Rio de Janeiro - RJ, Brasil. E-mail: carol_tulipa@yahoo.com.br 


\section{INTRODUCTION}

Fruits and vegetables are examples of important sources of essential elements. The fruits are rich in fibers, sugars, minerals, vitamins, organic acids and pigments. There has been an increase in the consumption of tropical fruits throughout the world because of their nutritional value, their use in some medicinal treatments, and even for the exotic flavor that they possess. The commerce of fruits is estimated in millions of dollars, and Brazil is the third largest producer of tropical fruits (KUSKOSKI et al., 2005).

The study of native or typical fruits contributes to a better exploration of national species and can motivate new economic activities. The search for more beneficial uses for residues from the food processing industry and the non-consumable portions of fruits could benefit the environment, as well as humans, through minimization of food waste.

Jabuticaba is a fruit of Brazilian origin, belonging to the Myrtaceae family and Myrciaria genus (BERG, 1857) that was changed to Plinia as proposed by Sobral (1985) and utilized by Mattos (1998), to reclassify the jabuticaba species. Among the species are $P$. cauliflora (DC) Berg, known as Paulista-jabuticaba or jabuticaba-açu; and P. jaboticaba (Vell.) Berg, known as Sabará, which is the most cultivated and commercialized in Brazil (SASSO et al. 2010). It is cultivated throughout Brazil, mainly in the Southeastern states. Jabuticaba trees are robust, perennial plants, with a productive phase of 30 to 50 years (GOMES, 1983). The fruits are consumed in natura, as liqueurs and as jellies. However, the increase in consumption leads to an increase in residues such as skins and seeds that are underused or not used at all.

Little is known of the chemical constituents of this fruit, especially those of its fractions. Recently, Lima et al. (2008) characterized two varieties of jabuticaba with respect to the centesimal composition, soluble solids, total titratable acidity and $\mathrm{pH}$ of the whole fruit and its fractions, as well as analyzed the bioactive or anti-nutrient compounds.

The aim of this work was to determine the sugar, organic acid and mineral compositions of the whole fruit and fractions (skin, pulp and seed), as well as the oil compositions of the skin and seeds of the Paulista (Plinia cauliflora) and Sabará (Plinia jaboticaba) jabuticaba tree genotypes, in order to expand the knowledge on the chemical constituents of the fruit, to motivate the use of the fruit - mainly the skins and seed fractions, which correspond to approximately $50 \%$ of the fruit (LIMA et al., 2008) - , as a low cost dietary alternative and in the food or cosmetics industry.

\section{MATERIAL AND METHODS}

Ripe fruit of two genotypes of the jabuticaba tree - Paulista (Plinia cauliflora) and Sabará (Plinia jaboticaba) were manually picked on an October morning in a farm located in São José do Ismeril, municipal district of Coqueiral, MG, Brazil (located at $21^{\circ} 14^{\prime}$ " S latitude and $45^{\circ} 27^{\prime} 2^{\prime \prime} \mathrm{W}$ longitude, with an altitude of 823 meters), in a region near Lavras. The local climate is classified by Köppen as Cwa (mild and rainy summer, with moderate temperature, an annual average bellow $21^{\circ} \mathrm{C}$ ). The average annual precipitation and relative humidity are, respectively, 1,500 $\mathrm{mm}$ and $70 \%$ (EMATER, 2002).

Soon after being picked, they were selected, washed, sanitized with sodium hypochlorite (200 $\mathrm{mg} \mathrm{L}^{-1}$ ) by immersion for 10 minutes, weighed and separated in whole fruit and in fractions (skin, pulp and seed) in three repetitions (of $3 \mathrm{~kg}$ each). The portion destined for the analysis of whole fruit was ground in a blender for 2 minutes, frozen in portions of known weight, and lyophilized to constant weight. The fruits were squeezed on a thick sieve, separating the skins, seeds and pulp, which were wrapped, weighed, frozen and lyophilized to constant weight.

The total sugars were extracted by the LaneEnyon methods (Association of Official Agricultural Chemists - AOAC, 1990) and determined by Somogyi (1945) and Nelson (1944) methods.

The extraction for determination of sugars and organic acids using high performance liquid chromatography (HPLC) was achieved by stirring $3.0 \mathrm{~g}$ of each sample with $20 \mathrm{~mL}$ of distilled water, followed by centrifugation at $10,000 \mathrm{~g}$ for $10 \mathrm{~min}$ utes at $30^{\circ} \mathrm{C}$. The residues were washed four times with the same amount of water in order to remove all sugar, and the supernatants were combined. An aliquot of each sample was filtered through $0.22 \mu \mathrm{m}$ Millipore membranes, GV (Durapore ${ }^{\mathrm{TM}}$ ).

For the determining sugars, a Shimatzu model LC-10AI (Shimatzu Corp., Japan) high performance liquid chromatography equipped with an infusion pump (model LC-10AI), refractive index detector (model RID-10 A), and a $4.6 \mathrm{~mm} \times 250 \mathrm{~mm} \times 5 \mu \mathrm{m}$ C18 Zorbax column (Agilent). The mobile phase was acetonitrile (J. T. Baker, HPLC grade), degassed under vacuum in an ultrasonic bath. The flow rate was $0.8 \mathrm{~mL} \mathrm{~min}^{-1}$ at a temperature of $30^{\circ} \mathrm{C}$. The quantification was achieved by comparison with analytical curves using glucose, fructose and sucrose standards from Supelco. 
The same chromatograph used for the determination of sugars was used for the analysis of organic acids, using a UV/VIS detector (model SPD $-10 \mathrm{AI})$ at $210 \mathrm{~nm}$; oven temperature of $50^{\circ} \mathrm{C}$ and a flow rate of $0.6 \mathrm{~mL} \mathrm{~min}^{-1}$. A Shim-Pack SCR $101 \mathrm{H}$ (7.9 $\mathrm{mm} \times 300 \mathrm{~mm}$ ) cation exchange column was used. Ultrapure water with $\mathrm{pH}$ adjusted to 2.1 with HPLC grade perchloric acid was used as the mobile phase. Certified standards of acetic (Merck ${ }^{\mathrm{TM}}$ ), succinic, oxalic, citric and malic acids (Supelco ${ }^{\mathrm{TM}}$ ) were used for the identification of the organic acids.

The mineral analysis involved a hot nitric acid-perchloric acid digestion of $0.5 \mathrm{~g}$ of each lyophilized sample. The calcium, magnesium, copper, manganese, iron, and selenium analyses were accomplished by atomic absorption spectrometry using a SpectrAA 110 (Varian INE) spectrometer, calibrated at the specific wavelength, aperture, and gas mixture conditions for each element. Phosphorus and sulfur were analyzed by UV/Vis spectrophotometry on a Perkin-Elmer $25 \mathrm{UV} /$ Vis spectrophotometer, and sodium and potassium were analyzed by flame emission photometry using a Micronal B262 apparatus. The procedures used for all of the analyses were those described by Malavolta et al. (1989). Standard Titrisol ampoules (Merck ${ }^{\mathrm{TM}}$ ) and ultrapure water (Milli-Q) were utilized for the construction of the analytical curves, with the concentrations varying according to the samples.

The extraction of lipids from the skins and seeds of the two jabuticaba tree genotypes was performed with a Soxhlet apparatus, using cartridges containing $10 \mathrm{~g}$ of sample. The samples were extracted with refluxing petroleum ether over a three-hour period. Several extractions were performed. After the extraction, the solvent was evaporated, and the oil was stored in amber flasks at $4{ }^{\circ} \mathrm{C}$.

The skin and seed oils were chromatographed on silica gel plates, using hexane/chloroform (60:40) as the mobile phase. The spots were visualized by heating with anisaldehyde at $105^{\circ} \mathrm{C}$ on a hot plate.

It was observed that the skins and the seeds of the two varieties presented the same chromatogram (Figure. 4).

Approximately $1 \mathrm{mg}$ of each sample was dissolved in $2 \mathrm{~mL}$ of dichloromethane, and a few drops of an ethereal solution of diazomethane were added for the methylation of the fatty acids. The solvents were evaporated with the aid of a stream of nitrogen gas. The solvent-free samples were again dissolved in dichloromethane to be analyzed by high resolution gas chromatography coupled to a mass spectrometer (HRGC-MS). The HRGC-MS was used for the separation and chemical characterization of the components present in the extracts of the skins and seeds of the two jabuticaba tree genotypes. All of the analyses were conducted using the same temperature program. A DB-1 $(30 \mathrm{~m} \times 0.25 \mathrm{~mm} \times 0.25 \mathrm{~mm})$ capillary column was used, and $1 \mu \mathrm{L}$ of each sample dissolved in dichloromethane was injected using the "hot needle" technique. The temperature program began at $80^{\circ} \mathrm{C}$, gradually increasing at $5^{\circ} \mathrm{C} /$ min to $270^{\circ} \mathrm{C}$, where it remained for 15 minutes. The injection mode was split flow (10:1), and the injection port and transfer line temperatures were $270^{\circ} \mathrm{C}$ and $280^{\circ} \mathrm{C}$, respectively. The carrier gas was helium (1.000 psi) and the solvent non-detection time was 5 minutes. The mass spectra were obtained in the range from 50 to $800 \mathrm{Da}$. The Wiley 275 (G1034C, Version C0300-Hewlett-Packard 1984-1994) data base was utilized.

The experiment was performed in a completely randomized design, with three replicates, in a $4 \times 2$ factorial outline, four being the number of fractions (whole fruit, skin, pulp and seed) and two jabuticaba tree genotypes (Paulista - Plinia cauliflora - and Sabará - P. jaboticaba). Average and Standard Deviation were used to compare data from chromatographic analyses. The statistical analysis was performed using the SISVAR program (FERREIRA, 2003); with the means being compared by the Scott-Knott test $(P \leq 0.05)$.

\section{RESULTS AND DISCUSSION}

The amount of sugars found in the skin and seed was high. This observation could partially be a result of the presence of pulp sugars that remained adhered to these fractions, in spite of the efforts to separate the fractions. A mucilaginous layer remained adhered to the jabuticaba seed even though it was scrubbed on a sieve. The same thing occurred with the skin. There was a slight difference in the sugar levels among the genotypes and fractions, mainly between the skins and seeds, but all sugars are present in higher amounts in pulps, with the Paulista presenting higher contents of total sugar and non-reducing sugar. The Sabará genotype presented higher levels of all sugars in the seeds. There was no variation between the two genotypes in the analysis of sugars in the whole fruit (Table 1).

While analyzing sugars in fruits under development of Sabará genotype of jabuticaba tree and using the same methods as the present work, Barros et al. (1996) found $60 \mathrm{~g} 100 \mathrm{~g}^{-1}$ of total sugars and

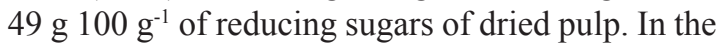
skins and seeds, much smaller amounts were found than in the present work. That difference can be 
due to the fact that the samples were picked in the month of July, a winter month, when the photoperiod is shorter. This fact could lead to a decrease in the amount of sugar in the fruit.

Sato and Cunha (2007), when analyzing fresh pulp of the Sabará genotype, found $11.80 \mathrm{~g}$

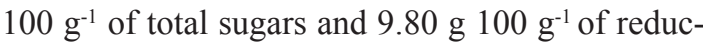
ing sugars. Transforming the levels found in the lyophilized pulp of the present work into fresh matter, the Paulista genotype presented $12.84{\mathrm{~g} 100 \mathrm{~g}^{-1}}^{-1}$

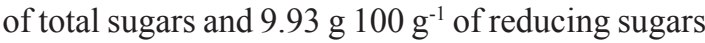

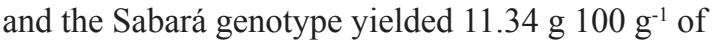

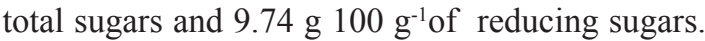
These results were very similar to those found by the aforementioned authors.

In the HPLC analysis, fructose, glucose and sucrose sugars were found in the whole fruit and in the fractions of the two jabuticaba tree genotypes. From the pulp sugars, fructose was present at higher levels than glucose, which in turn was higher than sucrose. The Paulista genotype presented a higher fructose and glucose level than the Sabará genotype. The Sabará genotype presented a higher sucrose level than that of the Paulista genotype (Table 2).

The sum of the sugar concentrations in the chromatographic analysis of the Paulista genotype

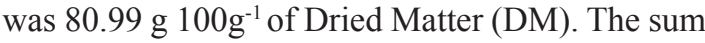
of the reducing sugars and sucrose in the colorimetric method was approximately $78.88{\mathrm{~g} 100 \mathrm{~g}^{-1}}^{-}$ of DM. In the Sabara genotype, the sum using the

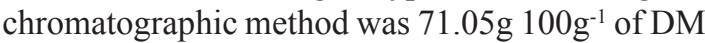

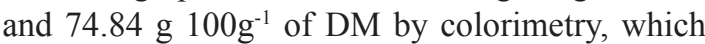
demonstrates the coherence of the two methods. The chromatogram of the sugars and the respective retention times for a pulp sample of the Paulista genotype is presented in Figure 1.

A study performed by Trevisan et al. (1972) with Sabará jabuticaba genotype using electrophoresis identified the same three sugars, thus being in agreement with the results obtained in the present work.

The following acids were found in the whole fruit and in the fractions of the two jabuticaba genotypes in quantitative order: citric $>$ succinic $>$ malic $>$ oxalic $>$ acetic, with the oxalic and acetic acids appearing in very low concentrations (Figure $2 \mathrm{~A}$ and $2 \mathrm{~B}$ ).

Jham et al. (2007) analyzed the organic acids in the pulp and skins of these same two genotypes of jabuticaba fruits picked in the region of Viçosa, MG, Brazil. The samples were analyzed by gas and liquid chromatography from the $20^{\text {th }}$ to the $42^{\text {nd }}$ day after flowering, during the development of the fruits. It is not clear if the fruits were ripe at the $42^{\text {nd }}$ day. The authors found only three organic acids, the highest levels being from the succinic acid, followed by citric acid, with only traces of malic acid. Those researchers verified that the concentrations of the organic acids vary as a function of the development and maturation of the fruit.

The occurrence of succinic acid concentrations higher than those of citric acid in the pulp in the aforementioned work can be a result of the employed extraction method, which might have favored the extraction of the succinic acid. Harvest time, fertilization, irrigation, solar intensity, cultivar and temperature are examples of other factors that may influence the levels of organic acids (DAVEY et al., 2000). Furthermore, Trevisan et al. (1972) only found citric and oxalic acid in the aqueous extract of the Sabará jabuticaba genotype using thin layer chromatography. This indicates that the method used can influence the results.

Mineral analysis of the whole jabuticaba fruit and its fractions showed that the highest concentration of calcium, magnesium, phosphorus, copper and iron were found in the seeds. In the Sabará genotype, calcium was well distributed among the fractions, and the levels of sodium, copper and iron were higher than those in the Paulista genotype (Table 3).

Among the minerals analyzed, potassium was the element that presented the highest levels, being larger in the skin fraction and whole fruit of the Sabará genotype. The levels in the pulp were the same for the two genotypes, and the Paulista genotype presented higher levels in the seeds than the Sabará.

Fruits are usually rich in potassium, mainly in the skins. According to Vanillo et al. (2006), potassium is an element that presents great mobility in plants, because of its low affinity for forming organic chelates, thus explaining the high concentrations in vegetable tissues.

Gondim et al. (2005), when analyzing skins of several dried fruits, verified that potassium presented the highest concentration among the analyzed minerals, with in natura tangerine presenting the highest

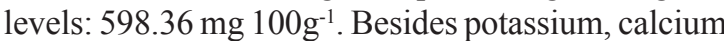
and magnesium were the most abundant minerals in the skins of the fruits analyzed by these authors.

Magnesium, as well as phosphorus and sodium, was also present in high levels in the jabuticaba seeds. In addition to the probable participation of magnesium in the green pigmentation of the fruit, the accumulation of the mineral in the jabuticaba skin suggests that its behavior is related to the accumulation of anthocyanins, since magnesium, according to Goodwin and Mercer (1983), is associated with alterations in the color of these pigments. The high 
concentration of phosphorus in the seed can be associated with the presence of phytin, a compound considered to be a reservoir for phosphorus for germination (MENGEL; KIRKBY, 1987).

Manganese stood out in the skins of the two genotypes, probably because it is related to fruit pigmentation. This element has an important role in the maintenance of the photosynthetic activity of the fruit (MARSCHNER, 1995).

Oliveira et al., 2003, while analyzing the Sabará genotype from several regions of São Paulo, found great variability of the mineral elements, demonstrating that different factors, such as soil fertility, climate, may influence the concentration of these elements.

Calculations of the mineral contributions of each fraction were made in relation to the recommended daily intake (RDI) for an adult (Table 4).

The jabuticaba fruit is not a good source of calcium, sodium or phosphorus. However, the skin of the Sabara genotype contains the equivalent of $75.9 \%$ of the daily potassium needs and even the pulp and seeds, which present lower levels, contribute with approximately $50 \%$ of this nutrient's recommended levels, which shows that the jabuticaba is a great source of potassium. The fruit is also a good source of magnesium, manganese and copper. The seeds are richer in magnesium, copper and iron. However, the skins contribute more to the RDI of manganese. The skins and seeds analyzed often present nutrient concentrations higher than that of their respective edible parts. The lyophilized (dehydrated) form of the fruit is an excellent form for use in the enrichment of foods and flour since it may be more readily stored.

The seed oils presented a light yellow color with a resinous smell and aspect. The skin oils presented a dark green color, as well as a resinous smell and aspect.

According to Lima et al. (2008), the quantities of ether extract obtained from the pulps of the two jabuticaba tree genotypes were very low: $0.06 \pm 0.02$ $\mathrm{g} 100 \mathrm{~g}^{-1}$ of DM in the Sabará genotype and $0.21 \pm$

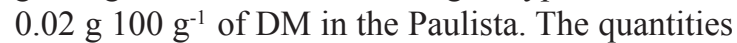
of ether extract obtained from the skins and seeds

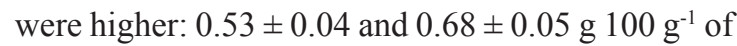
$\mathrm{DM}$ from the seed and skin fractions of the Paulista genotype, respectively, and $0.58 \pm 0.02$ and $0.57 \pm$

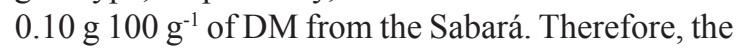
characterization of the lipids of these two skin and seed fractions were conducted. The lipids extracted from the skins of the two jabuticaba genotypes could not be identified due to interference. However, since the preliminary analysis obtained by TLC (Figure 3 ) indicated that the oils extracted from the skin and seed fractions seems to have a similar composition, the compounds identified in the seed oil can be considered as the same as those of the skin oil.

The triacylglycerols are usually the major components of vegetable oils. The minor components are monoglycerides and diglycerides, free fatty acids, phosphatides, sterols, alcohols, vitamins and other still unidentified substances (FREITAS et al., 2008). In this work the individual lipids were not quantified.

The seed oil chromatograms of the Sabará and Paulista genotypes are presented in Figure 4A and $4 \mathrm{~B}$ respectively.

In Table 5, the major compounds, their retention times, and respective relative average area percentages are shown.

The most abundant compound in the seeds was a phytosterol, an intermediate of sterol biosynthesis that could not be identified only by mass spectrometry and the standards library (Table 5). Linoleic acid (22.22 min.) and palmitic acid (19.06 min.) complete the three most abundant compounds. Oleic acid (22.40 min.), stearic acid (22.97 min.) and squalene (34.34 min.) were also identified. The peak at 39.60 min could not be identified (Figure 4B). As was verified in TLC, the seed oil from the Paulista genotype presented practically the same lipid composition as the Sabará genotype. Only the proportions were different.

The non-identified phytosterol presented a molecular ion at $\mathrm{m} / \mathrm{z}=414$ with a molecular formula $\mathrm{C}_{29} \mathrm{H}_{50} \mathrm{O}$. Palmitic acid was also the most abundant saturated fatty acid in the grape seed oil (FREITAS et al., 2008), as well as in passion fruit seed oil (FERRARI et al., 2004) and in the açaí pulp (MENEZES et al., 2008).

Squalene is a triterpene that acts as a biosynthetic precursor of all the plant and animal sterols. In spite of presenting a low concentration in the jabuticaba skin and seed lipid fractions, squalene is another constituent that enriches the fruit. Research has demonstrated that squalene presents antioxidant (KOHNO et al., 1995), anticarcinogenic (KO et al., 2002), hypocholesterolemic (MIETTINEM; VANHANEM, 1994) and cardioprotective activities (Farvin et al., 2004).

The components of jabuticaba seed oil are very similar to those of the grape seed oil. Again, the most abundant fatty acids were linoleic acid, representing almost $70 \%$ of the composition, and oleic acid, representing approximately $16 \%$ of the grape seed oil. The oil extracted from grape seeds is very much appreciated in the cosmetic industry. The jabuticaba seed oil could be similarly utilized. New 
studies should be undertaken to identify the phytosterol, quantify all the components and characterize them physicochemically so as to verify if the oil is within the standards established by the National
Sanitary Control Agency (ANVISA, 2009) for commercial oils, so that it may be used as a source of oil and minerals for human consumption.

TABLE 1 - Total soluble sugars, reducing and non-reducing sugars of whole fruit and its fractions of two jabuticaba tree genotypes ( $\mathrm{g} 100 \mathrm{~g}^{-1}$ of dry matter).

\begin{tabular}{|c|c|c|c|c|}
\hline & Total sugars ${ }^{\mathrm{a}}$ & \multicolumn{2}{|c|}{ Reducing sugars $^{\mathbf{a}}$} & Non-reducing sugars ${ }^{a}$ \\
\hline & Paulista $\quad$ Sabará & Paulista & Paulista & Sabará \\
\hline Skin & $46.57 \pm 0.43 \mathrm{bB} 38.93 \pm 1.56 \mathrm{aA}$ & $44.72 \pm 0.43 \mathrm{cB}$ & $33.24 \pm 1.74 \mathrm{aA} \quad 1.76 \pm 0.00 \mathrm{aA}$ & $5.41 \pm 0.88 \mathrm{bB}$ \\
\hline Pulp & $79.78 \pm 2.21 \mathrm{cB} 75.37 \pm 1.00 \mathrm{cA}$ & $61.71 \pm 4.06 \mathrm{dA}$ & $64.74 \pm 0.43 \mathrm{cA} 17.17 \pm 1.76 \mathrm{c} \mathrm{B}$ & $10.10 \pm 0.86 \mathrm{cA}$ \\
\hline Seed & $32.77 \pm 2.14 \mathrm{aA} 36.42 \pm 1.57 \mathrm{aB}$ & $29.64 \pm 2.29 \mathrm{aA}$ & $33.15 \pm 1.57 \mathrm{aB} \quad 2.97 \pm 0.24 \mathrm{aA}$ & $3.11 \pm 0.00 \mathrm{a} A$ \\
\hline $\begin{array}{l}\text { Whole } \\
\text { fruit }\end{array}$ & $48.33 \pm 1.16 \mathrm{bA} 45.91 \pm 2.07 \mathrm{bA}$ & $40.21 \pm 0.79 \mathrm{bA}$ & $39.46 \pm 1.19 \mathrm{bA} 7.70 \pm 1.22 \mathrm{~b} \mathrm{~A}$ & $6.13 \pm 0.92 \mathrm{bA}$ \\
\hline CV $(\%)$ & 3.22 & 4. & 13 & \\
\hline
\end{tabular}

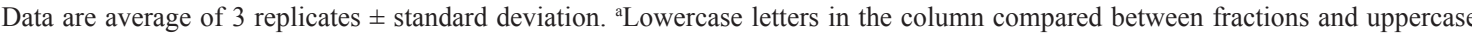
letters in the line compared between genotypes. The same letters do not differ among themselves by $\operatorname{Scott}-\operatorname{Knott} \operatorname{test}(P \leq 0.05)$

TABLE 2 - Sugars (g $100 \mathrm{~g}^{-1}$ dry matter) in the pulps of two jabuticaba tree genotypes by HPLC.

\begin{tabular}{lccc}
\hline Genotype & Fructose & Glucose & Sucrose \\
\hline Paulista & $38.25 \pm 4.57$ & $32.87 \pm 3.25$ & $9.87 \pm 0.27$ \\
Sabará & $32.96 \pm 2.68$ & $26.40 \pm 0.60$ & $11.69 \pm 0.21$ \\
\hline
\end{tabular}

Data are average of 3 replicates \pm standard deviation. Average moisture level of pulp: Paulista: 83.91 g 100 g$^{-1}$; Sabará: 84.95 g 100 g-1.

TABLE 3 - Minerals (mg 100g-1 dry matter) in whole fruit and its fractions of two varieties of jabuticaba ${ }^{\mathrm{a}}$.

\begin{tabular}{|c|c|c|c|c|c|}
\hline Paulista & Ca & $\mathbf{K}$ & Mg & $\mathbf{N a}$ & $\mathbf{P}$ \\
\hline Skin & $50.00 \pm 10.00 \mathrm{aA}$ & $1.206,67 \pm 56,86^{\mathrm{cA}}$ & $80.00 \pm 0.05 \mathrm{bA}$ & $62.18 \pm 2.86 \mathrm{bA}$ & $63.33 \pm 5.77 \mathrm{bA}$ \\
\hline Pulp & $43.33 \pm 5.77 \mathrm{aA}$ & $1.003,33 \pm 32,15^{\mathrm{aA}}$ & $66.67 \pm 5.77 \mathrm{aA}$ & $63.35 \pm 0.51 \mathrm{bA}$ & $53.33 \pm 5.77 \mathrm{aA}$ \\
\hline Seed & $70.00 \pm 10.00 \mathrm{bB}$ & $1.006,67 \pm 30,55$ а в & $110.00 \pm 10.00 \mathrm{cA}$ & $54.17 \pm 4.73 \mathrm{aA}$ & $106.67 \pm 5.77 \mathrm{dA}$ \\
\hline Whole Fruit & $60.00 \pm 0.00 \mathrm{bA}$ & $1.113,33 \pm 60,28^{\mathrm{bA}}$ & $86.67 \pm 5.77 \mathrm{bA}$ & $60.76 \pm 1.82 \mathrm{bA}$ & $73.33 \pm 5.77 \mathrm{cA}$ \\
\hline \multicolumn{6}{|c|}{ Sabara } \\
\hline Skin & $56.67 \pm 5.77 \mathrm{aA}$ & $1,496.67 \pm 5.77 \mathrm{~d} \mathrm{~B}$ & $90.00 \pm 0.05 \mathrm{bB}$ & $61.10 \pm 2.05 \mathrm{aA}$ & $63.33 \pm 5.77 \mathrm{aA}$ \\
\hline Pulp & $53.33 \pm 5.77 \mathrm{aA}$ & $1,026.67 \pm 56.67 \mathrm{~b} \mathrm{~A}$ & $73.33 \pm 5.77 \mathrm{aA}$ & $62.55 \pm 0.16 \mathrm{aA}$ & $56.67 \pm 5.77 \mathrm{aA}$ \\
\hline Seed & $56.67 \pm 5.77 \mathrm{aA}$ & $930.00 \pm 17.32$ a A & $116.67 \pm 5.77 \mathrm{dA}$ & $62.19 \pm 2.00 \mathrm{aB}$ & $110.00 \pm 5.77 \mathrm{cA}$ \\
\hline Whole Fruit & $56.67 \pm 5.77 \mathrm{aA}$ & $1,180.00 \pm 10.00 \mathrm{c} \mathrm{B}$ & $100.00 \pm 0.06 \mathrm{cB}$ & $61.12 \pm 1.96 \mathrm{aA}$ & $76.67 \pm 5.77 \mathrm{bA}$ \\
\hline CV (\%) & 12.13 & 3.04 & 5,97 & 3.89 & 7.16 \\
\hline Paulista & $\mathbf{C u}$ & Mn & $\mathrm{Fe}$ & $\mathbf{S}$ & $\mathrm{Se}$ \\
\hline Skin & $0.86 \pm 0.04 \mathrm{bA}$ & $1.69 \pm 0.52 \mathrm{bA}$ & $1.77 \pm 0.06 \mathrm{aA}$ & Trace & Trace \\
\hline Pulp & $0.65 \pm 0.04 \mathrm{aA}$ & $1.13 \pm 0.08 \mathrm{aA}$ & ND & Trace & Trace \\
\hline Seed & $1.19 \pm 0.02 \mathrm{cA}$ & $0.90 \pm 0.17 \mathrm{aA}$ & $3.75 \pm 0.08 \mathrm{bA}$ & Trace & Trace \\
\hline Whole Fruit & $0.87 \pm 0.01 \mathrm{bA}$ & $1.30 \pm 0.02 \mathrm{aA}$ & $5.92 \pm 0.83 \mathrm{cB}$ & Trace & Trace \\
\hline \multicolumn{6}{|l|}{ Sabara } \\
\hline Skin & $0.89 \pm 0.06 \mathrm{bA}$ & $1.71 \pm 0.11 \mathrm{bA}$ & $1.68 \pm 0.02 \mathrm{aA}$ & Trace & Trace \\
\hline Pulp & $0.69 \pm 0.02 \mathrm{aA}$ & $1.24 \pm 0.02 \mathrm{aA}$ & ND & Trace & Trace \\
\hline Seed & $1.46 \pm 0.01 \mathrm{cB}$ & $1.04 \pm 0.05 \mathrm{aA}$ & $5.22 \pm 0.17 \mathrm{cB}$ & Trace & Trace \\
\hline Whole Fruit & $0.93 \pm 0.0 \mathrm{bB}$ & $1.27 \pm 0.04 \mathrm{aA}$ & $2.59 \pm 0.23 \mathrm{bA}$ & Trace & Trace \\
\hline
\end{tabular}

CV (\%)

3.34

16.65

5.43

Data are average of 3 repetitions \pm standard deviation. ${ }^{a}$ Lowercase letters in the column compared between fractions and uppercase letters in the column compared between varieties. The same letters do not differ among themselves by Scott-Knott test $(P \leq 0.05)$. $\mathrm{ND}=$ Not determined 
TABLE 4 - Percentage of recommended daily intake (RDI) for an adult based on $100 \mathrm{~g}$ of whole fruit and fractions of two genotypes of lyophilized jabuticaba.

\begin{tabular}{lcccccccc}
\hline Paulista & Ca & K & Mg & Na & P & Cu & Mn & Fe \\
\hline Skin & 6.3 & 61.2 & 26.7 & 3.2 & 7.9 & 28.7 & 33.8 & 12.6 \\
Pulp & 5.4 & 50.9 & 22.2 & 3.3 & 6.7 & 21.7 & 22.6 & - \\
Seed & 8.8 & 51.0 & 36.7 & 2.8 & 13.3 & 39.7 & 18.0 & 26.8 \\
Whole Fruit & 7.5 & 56.4 & 28.9 & 3.1 & 9.2 & 29.0 & 26.0 & 42.3 \\
\hline Sabara & & & & & & & & \\
\hline Skin & 7.1 & 75.9 & 30.0 & 3.2 & 7.9 & 29.7 & 34.2 & 12.0 \\
Pulp & 6.7 & 52.0 & 24.4 & 3.2 & 7.1 & 23.0 & 24.8 & - \\
Seed & 7.1 & 47.1 & 38.9 & 32 & 13.8 & 487 & 20.8 & 37.3 \\
Whole Fruit & 7.1 & 59.8 & 33.3 & 3.1 & 9.6 & 31.0 & 25.4 & 18.5 \\
\hline
\end{tabular}

TABLE 5- Average area of the major constituents of the lyophilized lipid fraction from seeds of the Paulista and Sabará genotypes of jabuticaba.

\begin{tabular}{lccc}
\hline & $\begin{array}{c}\text { Retention time } \\
\text { Constituent }\end{array}$ & \multicolumn{2}{c}{ Area (\%) } \\
\cline { 3 - 4 } & 19.06 & Paulista & Sabara \\
\hline Palmitic acid & 22.22 & 15.23 & 6.23 \\
Linoleic acid & 22.40 & 3.98 & 10.48 \\
Oleic acid & 34.34 & 4.49 & 1.34 \\
Squalene & 41.11 & 24.15 & 1.68 \\
Phytosterol (NI)* & & &
\end{tabular}

$* \mathrm{NI}=$ Not identified

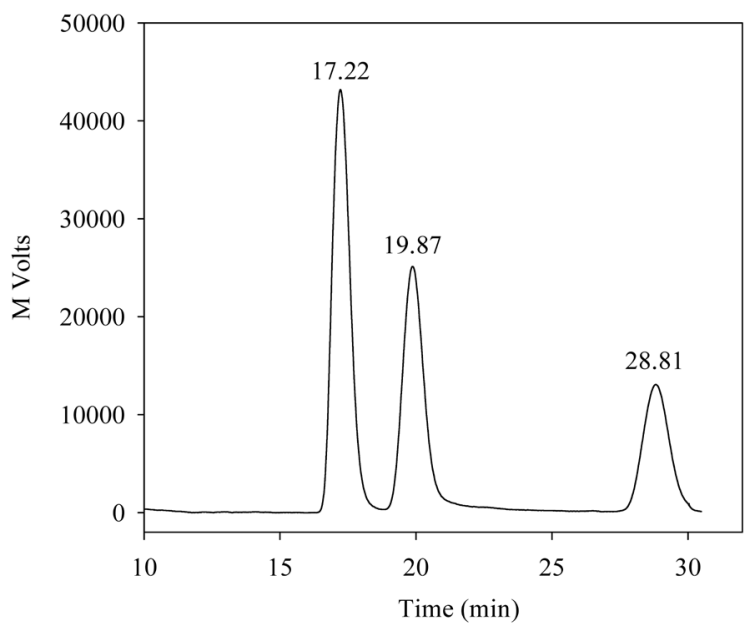

FIGURE 1 - Chromatogram of sugars in pulp from the Paulista jabuticaba jabuticaba genotype determined by HPLC. The peak at $17.22 \mathrm{~min}$. refers to fructose, at $19.87 \mathrm{~min}$. to glucose, and at 28.81 min. to sucrose. 


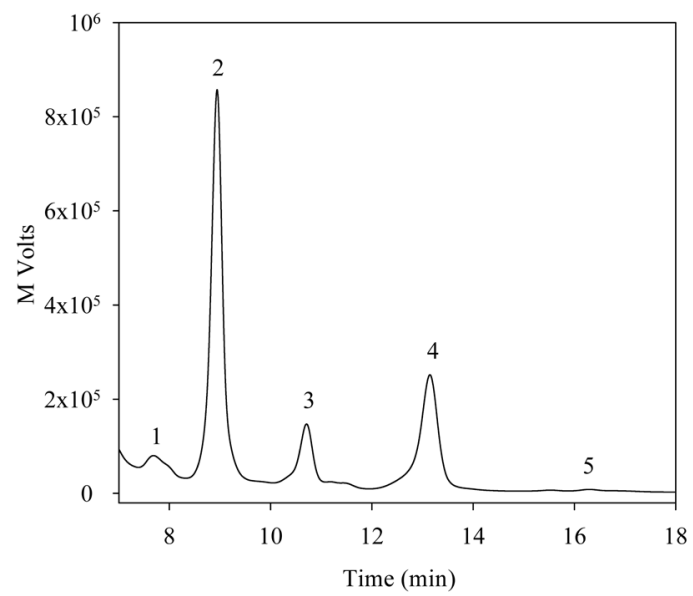

FIGURE 2A - Chromatogram of organic acids in the pulp from the Sabará jabuticaba genotype by HPLC. Peaks: $1=$ Oxalic, $2=$ Citric, $3=$ Malic, $4=$ Succinic, $5=$ Acetic.

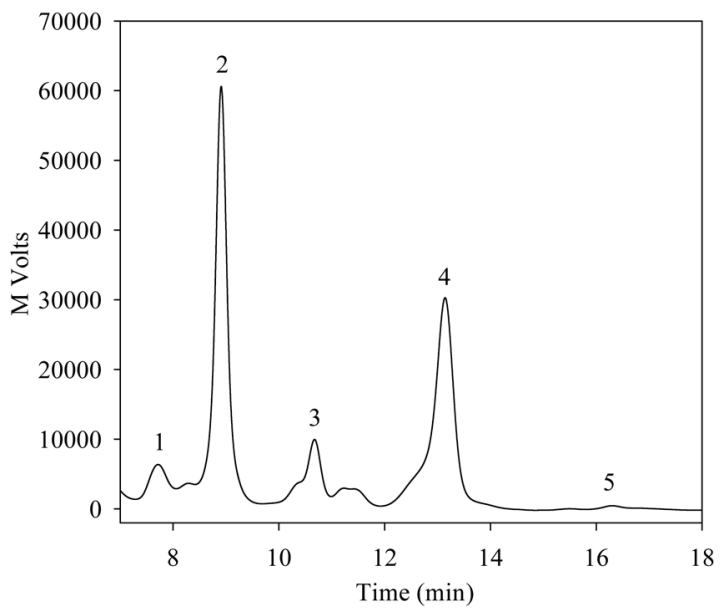

FIGURE 2B - Chromatogram of organic acids from skin of Paulista jabuticaba genotype by HPLC. Peaks: $1=$ Oxalic, $2=$ Citric, $3=$ Malic, $4=$ Succinic, $5=$ Acetic.

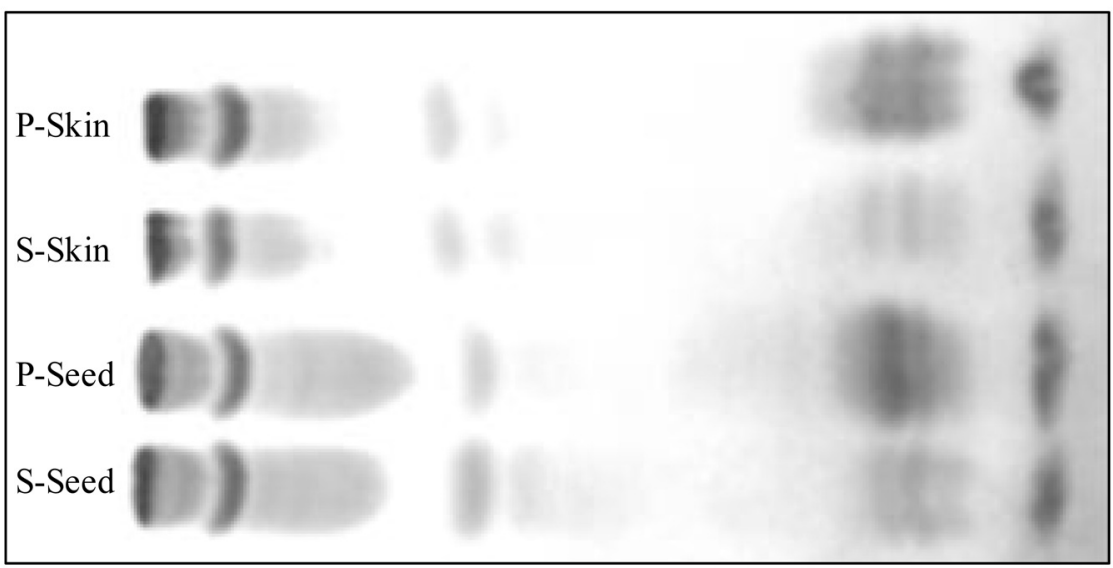

FIGURE 3 - Thin layer chromatography (TLC) of the skin and seed oil of two genotypes of jabuticaba. P $=$ Paulista; $\mathrm{S}=$ Sabará. 


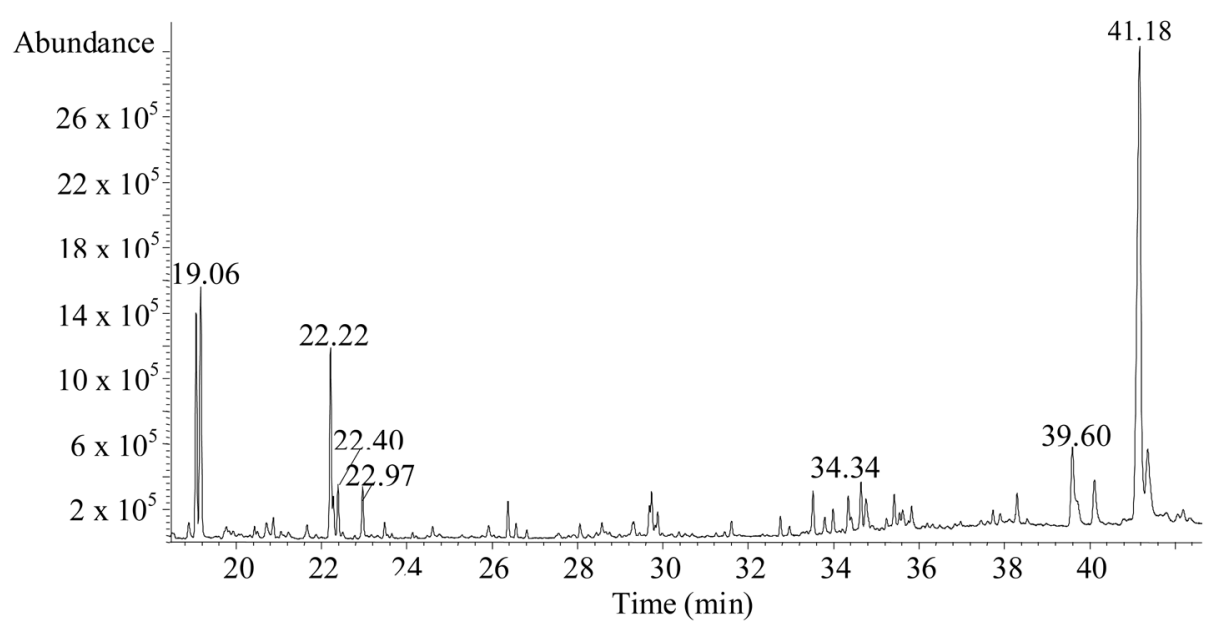

FIGURE 4A - Chromatogram of the lipid fraction of the seed oil from Sabará jabuticaba genotype.

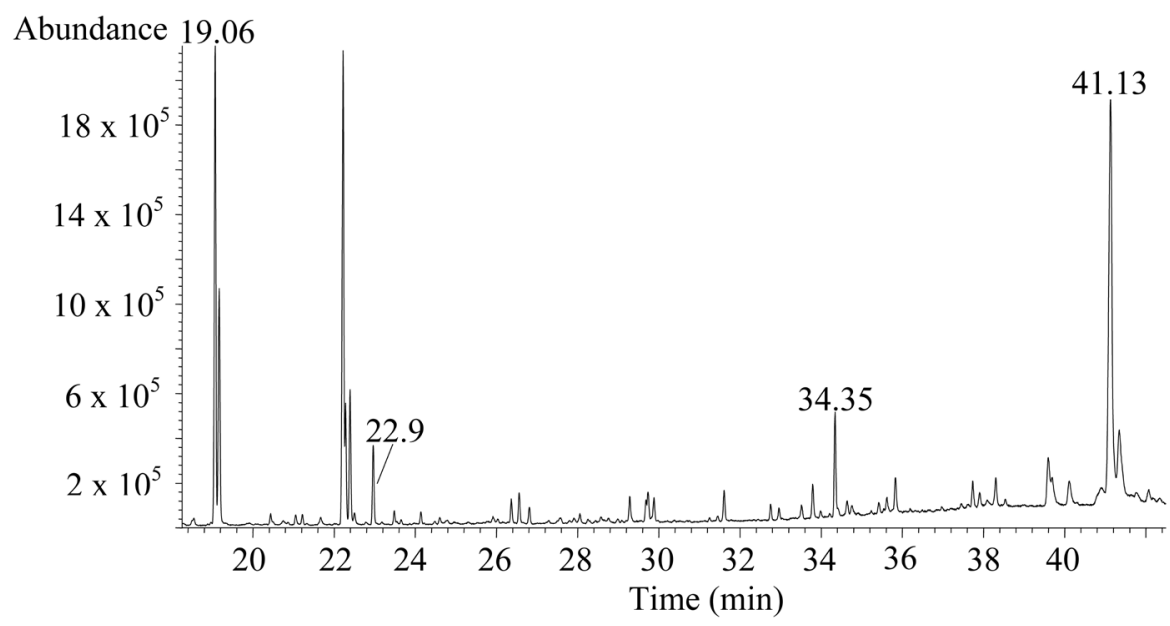

FIGURE 4B - Chromatogram of lipid fraction of the seed oil from the Paulista jabuticaba genotype.

\section{CONCLUSION}

1-High levels of sugar, especially fructose, followed by glucose and sucrose, were encountered in both genotypes of jabuticaba fruits analyzed. The pulp and skin of the Paulista genotype presented higher levels of total and reducing sugars than the Sabará genotype. The same does not occur when comparing whole fruits.

2-Five organic acids were found in the whole fruit and in the fractions of the two jabuticaba genotypes in quantitative order: citric acid $>$ succinic acid $>$ malic acid $>$ oxalic acid $>$ acetic acid.
3-The whole fruit, as well as the lyophilized skin, pulp and seed fractions, can be considered as an alternative source of minerals, mainly iron, potassium, magnesium and manganese, as well as phosphorus, calcium and copper.

4-In both genotypes, the seed oil had nearly the same constitution as the oil extracted from the skin, with the major compounds being an unidentified phytosterol, palmitic, linoleic and oleic acids, and squalene. The jabuticaba oil presents characteristics similar to those of grape seed oil, which is widely used in cosmetics, and of other edibles oils. 


\section{ACKNOWLEDGMENTS}

The authors thank the Fundação de Amparo à Pesquisa do Estado de Minas Gerais (FAPEMIG) for funding the project and for the doctoral (A.J.B.L.) and the scientific initiation scholarship (A.P.C.A) and the Conselho Nacional de Desenvolvimento Científico e Tecnológico (CNPq) for the scientific initiation scholarship (M.P.M.).

\section{REFERENCES}

ANVISA - Agencia Nacional de Vigilância Sanitária. Ingestão diária recomendada (IDR) para proteínas, vitaminas e minerais. Disponível em: $<\mathrm{http}: /$ www.anvisa.gov.br/base/visadoc/CP/CP[8989-1-0] pdf $>$. Acesso em: 16 jan. 2009.

AOAC. Official methods of analysis. Association of official analytical chemists. $15^{\text {th }}$ ed. Washington, 1990.

BARROS, R. S.; FINGER, F. L.; MAGALHÃES, M. M. Changes in non-structural carbohydrates in developing fruit of Myrciaria jabuticaba. Scientia Horticulturae, Amsterdam, v. 66, n. 3/4 p. 209-215, 1996.

DAVEY, M. W.; MONTAGU, M. van.; INZE, D.; SANMARTIN, M.; KANELLIS, A.; SMIRNOFF, N. Plant L-ascorbic: chemistry, function, metabolism, bioavailable and effects of processing. Journal of the Science of Food and Agriculture, London, v. 80, n. 7 , p. 825-860, 2000.

EMATER- Empresa de Assistência Técnica e Extensão Rural do Estado de Minas Gerais. Área de proteção ambiental do Município de Coqueiral. Belo Horizonte: Unidade de Consultoria e Projetos, 2002.

FARVIN, K. H. S.; ANANDAN, R.; KUMAR, S. H. S.; SHINY, K. S.; SANKAR, T. V.; THANKAPPAN, T. K. Effect of squalene on tissue defense system in isoprotereno-induced myocardial infarction in rats. Pharmacological Research, London, v. 50, n. 3, p. 231-236, 2004.

FERRARI, R. A.; COLUSSI, F.; AYUB, R.A. Caracterização de subprodutos da industrialização do maracujá-aproveitamento das sementes. Revista Brasileira de Fruticultura, Jaboticabal, v. 26, n. 1, p. 101-102, 2004.
FERREIRA, D. F. Sisvar: versão 4.6 (build 61) software. Lavras: Dex/UFLA, 2003. Disponível em: $<$ http://www.dex.ufla.br/danielff/dff02.htm>. Acesso em: 18 jun. 2006.

FREITAS, L. dos S.; OLIVEIRA, J. V. de; DARIVA, C.; JACQUES, R. A.; CARAMÃO, E. B. Extraction of grape seed oil using compressed carbon dioxide and propane: extraction yields and characterization of free glycerol compounds. Journal of Agricultural and Food Chemistry, Easton, v. 56, n. 8, p. 2558 2564, 2008 .

GOMES, R. P. Fruticultura brasileira. 9. ed. São Paulo: Nobel, 1983. 446 p.

GONDIM, J. A. M.; MOURA, M. F. V.; DANTAS, A. S.; MEDEIROS, R. L. S.; SANTOS, K. M. Composição centesimal e de minerais em cascas de frutas. Ciência e Tecnologia de Alimentos, Campinas, v. 25, n. 4 , p. $825-827,2005$.

GOODWIN, T. W.; MERCER, E. I. Introduction to plant biochemistry. Oxford: Pergamon, 1983. $677 \mathrm{p}$.

JHAM, G. N.; FERNANDES, S. A.; GARCIA, C. F.; PALMQUIST, D. Comparison of GC and HPLC for quantification of organic acids in two jaboticaba (Myrciaria) fruit varieties. Química Nova, São Paulo, v. 30, n. 7, p.1529-1534, 2007.

KO, T. F.; WENG, Y. M.; CHIOU, Y. Y. Squalene content and antioxidant activity of Terminalia catappa leaves and seeds. Journal of Agricultural and Food Chemistry, Easton, v. 50, n. 19, p. 5343-5348, 2002.

KOHNO, Y.; EGAWA, Y.; ITOH, S.; NAGAOKA, S.; TAKAHASHI, M.; MUKAI, K. Kinetic study of quenching reaction of singlet oxygen and scavenging raction of free radical by squalene in n-butanol. Biochimica et Biophysica Acta (BBA) - Lipids and Lipid Metabolism, Amsterdam, v. 1256, n. 1, p. 52-56, 1995.

KUSKOSKI, E.M.; ASUERO, A.G.; TRONCOSO, A.M.; MANCINI-FILHO, J.; FETT, R. Aplicación de diversos métodos químicos para determinar actividad antioxidante en pulpa de frutos. Ciência e Tecnologia de Alimentos, Campinas, v.25, n.4, p.726-732, 2005. 
LIMA, A.J.B.; CORRÊA, A.D.; ALVES, A.P.C.; ABREU, C.M.P.; DANTAS-BARROS, A.M. Caracterização química do fruto jabuticaba (Myrciaria cauliflora Berg) e de suas frações. Archivos Latinoamericanos de Nutrición, Caracas, v.58, n.4, p.416-421, 2008.

MALAVOLTA, E.; VITTI, G. C.; OLIVEIRA, S. A. Avaliação do estado nutricional das plantas: princípios e aplicações. Piracicaba: POTAFÓS, 1989. $201 \mathrm{p}$.

MARSCHNER, H. Mineral nutrition of higher plants. $2^{\text {th }}$ ed. San Diego: Academic, 1995. 889 p.

MATTOS, J.L.R. Fruteiras nativas do Brasil: jaboticabeiras. Porto Alegre: Nobel, 1983. 92p.

MENEZES, E. M. S.; TORRES, A. T.; SABAA SRUR, A. U. Valor nutricional da polpa de açaí (Euterpe oleracea Mart) liofilizada. Acta Amazônica, Manaus, v. 38, n. 2, p. 311-316, 2008.

MENGEL, K.; KIRKBY, E. A. Principles of plant nutrition. $4^{\text {th }}$ ed. Switzerland: International Potash Institute, $1987.687 \mathrm{p}$.

MIETTNEM, T. A.; VANHANEN, H. Serum concentration and metabolismo of cholesterol during repessed oil and squalene feeding. American Journal of Clinical Nutrition, New York, v. 59, n. 2, p. 356-363, 1994.

NELSON, N. A. A photometric adaptation of Somogyi method for determination of glucose. Journal of Biological Chemistry, Bethesda, v. 153, n. 1, p. 375-380, 1944.
OLIVEIRA, A.L.; BRUNINI, M. A.; SALANDINI, C.A. R.; BAZZO, F.R. Caracterização tecnológica de jabuticabas 'Sabará' provenientes de diferentes regiões de cultivo. Revista Brasileira de Fruticultura, Jaboticabal. v. 25, n.3, p. 397-400, 2003.

SASSO, S. A. Z.; CITADIN, I.; DANNER, M. A. Propagação de jabuticabeiras para enxertia e alporquia. Revista Brasileira de Fruticultura, Jaboticabal, v. 32, n. 2, p. 571-577, 2010.

SATO, A. C. K.; CUNHA, R. L. Influência da temperatura no comportamento reológico da polpa de jabuticaba. Ciência e Tecnologia de Alimentos, Campinas, v. 27, n. 4, p.890-896, 2007.

SOBRAL, M. Alterações Nomenclaturais em Plinia (Myrtaceae). Boletim do Museu Botânico de Curitiba, Curitiba, n. 63, p.1-4, 1985.

SOMOGYI, M. A. New reagent for determination of sugars. The Journal of Biological Chemistry, Bethesda, v. 160, p. 61-68, 1945.

TREVISAN, L.M.; BOBBIO, F.O.; BOBBIO, P.A. Carbohydrates, organic acids and anthocyanins of Myrciaria jaboticaba, Berg. Journal of Food Science, Chicago, v. 37, p. 818-819, 1972.

VANILLO, M. I.; LAMARDO, L. C. A.; GABERLOTTI, E. O.; MORENO, P. R. H. Composição química dos frutos de Campomanesia adamantium (Cambessédes) O. BERG. Ciência e Tecnologia de Alimentos, Campinas, v. 26, n. 4, p. 805-810, 2006. 